\title{
CYP7B1 wt Allele
}

National Cancer Institute

\section{Source}

National Cancer Institute. CYP7B1 wt Allele. NCI Thesaurus. Code C114942.

Human CYP7B1 wild-type allele is located in the vicinity of 8q21.3 and is approximately $211 \mathrm{~kb}$ in length. This allele, which encodes 25 -hydroxycholesterol 7-alpha-hydroxylase enzyme, is involved in cholesterol catabolism. Mutation of the gene is associated with autosomal recessive spastic paraplegia 5A and congenital bile acid synthesis defect 3 . 